\title{
ANALISIS DAMPAK PROGRAM REVITALISASI PASAR TRADISIONAL DI PASAR TUMENGGUNGAN TERHADAP PENDAPATAN PEDAGANG DAN EVALUASI MANAJEMEN TATA KELOLA PEDAGANG PASAR TUMENGGUNGAN PASCA PROGRAM REVITALISASI MENURUT PERSEPSI PEDAGANG
}

\author{
Siti Nur Azizah \\ sitinuraziz@yahoo.com
}

STIE PUTRA BANGSA

\begin{abstract}
Abstrak
The aim of this study is to analyze the income of the sellers on Tumenggungan market and evaluation of governance market traders post Tumenggungan revitalization program perception by traders. The data used are primary data, consisted of the sellers income before and after the market revitalization programm. The result of this research shows that the sellers income before and after the market revitalization programm are significanly different. Based on the survey results revealed all the indicators of input, process and output of the revitalization program Tumenggungan perceived market traders have increased. Therefore we can conclude the market revitalization program Tumenggungan a positive impact on revenue management and governance of the better post revitalization program
\end{abstract}

Keywords : income, market revitalization

\section{Latar Belakang}

Berdasarkan Peraturan Presiden Republik Indonesia No. 112 th. 2007, Pasar merupakan area tempat jual beli barang dengan jumlah penjual lebih dari satu baik yang disebut sebagai pusat perbelanjaan, pasar tradisional, pertokoan, mall, plaza, pusat perdagangan maupun sebutan lainnya. Secara fisik pasar dapat diartikan sebagai tempat bertemunya penjual dan pembeli untuk melakukan transaksi jual beli. Secara luas Kotler dan Amstrong (1999), mendefinisikan pasar sebagai seperangkat pembeli aktual dan potensial dari sebuah produk atau jasa. Ukuran dari pasar sendiri tergantung pada jumlah orang yang menunjukan kebutuhan, memiliki kemampuan dalam pertukaran.
Pada tataran praktis, pasar memiliki manfaat tersendiri bagi pedagang (penjual) maupun pembeli (konsumen). Bagi penjual, pasar dijadikan sebagai sarana untuk mendisplay produk yang akan ditawarkan kepada pembeli, sedangkan bagi pembeli pasar dijadikan sebagai sarana untuk menemukan produk yang dibutuhkan. Menurut Hanafi (2010), Pasar mencakup keseluruhan permintaan dan penawaran, serta seluruh kontak antara penjual dan pembeli untuk mempertukarkan barang dan jasa. Manfaat pasar akan dapat dimaksimalkan apabila ada pengelolaan pasar yang baik.

Pasar Tumenggungan merupakan pasar tradisional terbesar di Kabupaten Kebumen. Berdasarkan Peraturan Bupati Nomor 70 Tahun 2013 Pasar Tumenggungan merupakan pasar daerah 
pasar yang didirikan, dimiliki, dikuasai dan dikelola oleh Pemerintah Daerah Kabupaten Kebumen.

Berdasarkan data yang diperoleh dari Kepala UPT Pasar Tumenggungan, Pasar ini mampu menampung pedagang sebanyak 3.000 orang. Menurut Jumali (2011), munculnya sebuah kota banyak diawali dengan berkembangnya suatu pasar. Hal ini disebabkan karena pasar berperan mengumpulkan anggota masyarakat untuk melakukan transaksi jual-beli. Pasar Tumenggungan Kebumen sama halnya dengan pasar pada umumnya, dimana tumbuh berkembang sejalan dengan perkembangan Kota Kebumen beserta dinamika kehidupan masyarakat.

Berdirinya pasar Tumenggungan selain karena terkena dampak semakin kompleknya aktifitas perekonomian masyarakat, juga didorong oleh tantangan untuk menyediakan produk sebagai kebutuhan masyarakat Kabupaten Kebumen. Pada awalnya Pasar Tumenggungan hanyalah sebuah pasar Desa yang dimiliki oleh Desa Kebumen. Pasar Tumenggungan merupakan penggabungan antara dua pasar di Kota Kebumen, yaitu antara pasar Sungai Luk Ulo dengan Pasar Desa Kebumen. Menurut Jumali (2011), Pasar Tumenggungan diperkirakan dibangun pada tahun 1670-an. Pada tahun 2013 Pemerintah Kabupaten Kebumen melakukan revitalisasi pasar tersebut. Hal ini dilakukan Pemerintah Kabupaten Kebumen sebagai upaya beradaptasi dengan munculnya pasarpasar modern yang lebih bersih dan nyaman. Sebelum di revitalisasi kondisi fisik bangunan sudah tua, penataan pedagang masih semerawut, jika hujan becek, banyaknya parkir liar. Tujuan lain dari revitalisasi pasar Tumenggungan adalah untuk lebih menarik pembeli berbelanja di pasar tradisional sehingga terjadi peningkatan transaksi jual beli, secara otomatis pendapatan pedagang mengalami peningkatan. Selain itu revitalisasi pasar Tumenggungan juga diharapkan mampu menampung jumlah pedagang yang lebih banyak.

Berdasarkan pasal 27 ayat 2 UUD 45 menyebutkan bahwa tiap-tiap warga Negara berhak atas pekerjaan dan penghidupan yang layak. Artinya revitalisasi pasar Tumenggungan juga sebagai upaya pemerintah yang memiliki keterbatasan dalam menyediakan lapangan pekerjaan formal

Revitalisasi pasar Tumenggungan tidak hanya merujuk kepada perbaikan infrastruktur fisik, tetapi juga merujuk kepada sistem tata kelola pedagang. Pengelolaan pasar tradisional adalah merubah cara pandang yang lebih visioner, kreatif, partisipatif sehingga menjembatani akses produk lokal kepada masyarakat termasuk dalam membina dan bekerjasama dengan pedagang dan paguyuban pedagang.

Berdasarkan observasi pra penelitian dan wawancara dengan pedagang, Adanya revitalisasi pasar Temanggungan yang menghabiskan dana senilai 51,9 miliar rupiah ternyata belum menghasilkan sesuatu yang diharapkan oleh pedagang. Pada awalnya pedagang berharap setelah pasar direvitalisasi akan berdampak terhadap peningkatan pendapatan yang signifikan. Pada faktanya kunjungan pembeli ke pasar Tumenggungan tidak mengalami peningkatan secara signifikan, terutama kunjungan pembeli di lantai II.

Permasalahan lain dari adanya program revitalisasi pasar di beberapa kota adalah pasar kembali semrawut serta kondisi pasar kembali kumuh dan kotor sama keadaannya seperti sebelum dilakukan renovasi. Hal ini disebabkan karena pengelola pasar kurang mendapatkan pelatihan tentang manajemen pasar dan kurang dibekali cara menyusun prosedur kerja dan 
pengawasan tentang tata kelola pasar yang baik. Hal lain yang menyebabkan kegagalan adalah para pedagang eceran tidak dilatih untuk merencanakan pembelian (kulakan) barang dan persedian (stok), sortasi, pengemasan, penataan dan penyimpanan barang serta manajemen keuangan sederhana.

Sesuai dengan hubungan yang telah dibatasi maka dibangun rumusan masalah sebagai berikut:

1.Apa dampak program revitalisasi pasar tradisional terhadap peningkatan pendapatan pedagang di Pasar Tumenggungan?

2. Bagaimanakah tata kelola pedagang Pasar Tumenggungan pasca program revitalisasi?

\section{TINJAUAN PUSTAKA}

\section{Pengertian Pasar}

Secara fisik pasar merupakan tempat pemusatan beberapa atau kelompok pedagang tetap dan tidak tetap yang terdapat pada suatu ruangan terbuka atau tertutup atau sebagian badan jalan. Selanjutnya pengelompokkan para pedagang eceran tersebut menempati bangunan-bangunan dengan kondisi bangunan temporer, semi permanen ataupun permanen.

Menurut Ehrenberg dan Smith (2003), pasar merupakan tempat pertemuan antara pembeli dan penjual, di mana barang atau jasa sebagai produk yang dipertukarkan. Ukuran kerelaan dalam pertukaran tersebut biasanya akan muncul suatu tingkat harga atas barang dan jasa yang dipertukarkan. Akan terjadi sebuah transaksi apabila penjual dan pembeli menyepakati nilai yang harus dibayarkan untuk sebuah manfaat produk, meskipun pada akhirnya sebuah transaksi bisa saja tidak menguntungkan salah satu pihak. Syarat terjadinya transaksi adalah ada barang yang diperjual belikan, ada pedagang, ada pembeli, ada kesepakatan harga barang, dan tidak ada paksaan dari pihak manapun. Hasibuan (1994), menyatakan bahwa secara sederhana pasar sebagai pertemuan antara penjual dengan pembeli. Penjual disini tidak hanya berarti orang atau kelompok yang secara fisik mendisplay sebu sudut pandang, yaitu secara nyata dan dapat pula secara abstrak. Secara abstrak pasar adalah kontak ratusan atau ribuan perusahaan dalam suatu industri yang melakukan transaksi dalam suatu waktu, sedangkan secara nyata pasar merupakan terjadinya suatu transaksi jual beli yang terjadi pada suatu lokasi.

\section{Perbedaan Pasar Tradisional dan Pasar Modern}

Berdasarkan Keputusan Menteri Perindustrian dan Perdagangan RI No. 420/MPP/Kep/10/1997 tentang pedoman dan pembinaan pasar dan pertokoan, pasar diklasifikasikan berdasarkan kelas mutu pelayanan menjadi 2 (dua), yaitu :

\section{Pasar Tradisional}

Pasar tradisional adalah pasar yang dibangun dan dikelola oleh Pemerintah, Swasta, Koperasi, atau Swadaya Masyarakat dengan tempat usaha berupa toko, kios, los dan tenda, yang dimiliki atau dikelola oleh pedagang kecil dan menengah, dan koperasi, dengan usaha skala kecil dan modal kecil, dan dengan proses jual beli melalui tawar-menawar. Menurut Agustiar (dalam Fitri, 1999), organisasi pasar tradisional masih sangat sederhana, tingkat efisiensi dan spesialisasi yang rendah, lingkungan fisik yang kotor dan pola bangunan yang sempit. Pelaksanaan transaksi jual beli pada pasar tradisional juga dilakukan secara sederhana, dimana pembeli serta penjual yang bertemu secara langsung. 
Proses jual-beli biasanya melalui proses tawar menawar harga, dan harga yang diberikan untuk suatu barang bukan merupakan harga tetap.

Esther dan Didik (2003), menyatakan bahwa pasar tradisional memiliki kekuatan dan kelemahan di berbagai aspek. Pasar tradisional memiliki beberapa kekuatan di antaranya harganya yang lebih murah dan bisa ditawar, dekat dengan permukiman, dan memberikan banyak pilihan produk yang segar. Kelebihan lainnya adalah pengalaman berbelanja yang luar biasa, dimana kita bisa melihat dan memegang secara langsung produk yang umumnya masih sangat segar. Sedangkan, kelemahan pasar tradisional antara lain adalah kesan bahwa pasar terlihat becek, kotor, bau an terlalu padat lalu lintas pembelinya. Kelemahan lain adalah adanya ancaman bahwa keadaan sosial masyarakat yang berubah, di mana wanita di perkotaan umumnya berkarir sehingga menginginkan sesuatu yang praktis dan hampir dipastikan tidak memiliki waktu untuk berbelanja ke pasar tradisional.

\section{Pasar Modern}

Pasar modern merupakan pasar yang dibangun oleh Pemerintah, Swasta, atau Koperasi yang dalam bentuknya berupa mall, supermarket, Departement Store dan shoping centre dimana pengelolanya dilaksanakan secara modern, dan mengutamakan pelayanan dan kenyamanan berbelanja dengan manajemen berada disatu tangan, bermodal relatif kuat, dan dilengkapi label harga yang pasti. Sedangkan pasar modern adalah jenis pasar dimana penjual dan pembeli tidak bertransakasi secara langsung melainkan pembeli melihat label harga yang tercantum dalam barang (barcode), berada dalam bangunan dan pelayanannya dilakukan secara mandiri (swalayan) atau dilayani oleh pramuniaga. Contoh dari pasar modern adalah pasar swalayan, hypermarket, supermarket, dan minimarket. Ciri-ciri pasar modern antara lain harga sudah tertera dan diberi barcode, barang yang dijual beraneka ragam dan umumnya tahan lama, berada dalam bangunan dan pelayanannya dilakukan sendiri (swalayan), ruangan ber-AC, nyaman tidak terkena terik panas matahari, tempat bersih serta tata tempat sangat diperhatikan untuk mempermudah dalam pencarian barang. Pembayaran dilakukan dengan membawa barang ke kasir dan tidak ada tawar menawar lagi.

Saat ini telah terjadi persaingan yang dinamis antara pasar tradisional dan modern yang mengakibatkan posisi pasar tradisional mengalami pergeseran yang diduga karena terjadinya penurunan daya tarik pasar tradisional seiring dengan perubahan dinamis pasar modern yang sangat peduli dengan kualitas pelayanan yang excellent dan manajemen yang baik. Semakin maraknya pendirian pasar modern dan semakin banyaknya kehadiran para pedagang informal di wilayah perkotaan menjadi salah satu pretanda semakin ketatnya persaingan yang harus dihadapi para pedagang yang berlokasi di pasar tradisional. Fenomena yang terjadi pelanggan lebih memilih berbelanja di tempat yang memberikan kemudahan serta kenyamanan, baik akses menuju pasar, infra struktur pasar, maupun pelayanan yang diberikan pedagang. Disisi lain gaya berdagang para pedagang di pasar tradisional yang tidak berubah menyebabkan banyak pembeli beralih ke pasar moderen.

\section{Revitalisasi Pasar Tradisional}

Pelaksanaan revitalisasi pasar tradisional merupakan usaha Pemerintah agar pasar tradisional mampu bersaing 
dengan pasar modern. Pembangunan suatu pasar perlu memperhatikan kesejahteraan pedagang maupun pembeli di pasar tersebut. Lewat penataan kembali pasar tradisional yang memperhatikan aspek kenyamanan, pelayanan dan keamanan, maka potensi yang dimiliki pasar tradisional akan dapat meningkat. Menurut Danisworo (2000), revitalisasi merupakan suatu upaya yang dilakukan untuk memvitalkan kembali suatu kawasan atau bagian kota yang dulunya pernah hidup, namun mengalami degradasi oleh perkembangan zaman. Sehingga revitalisasi pasar tradisional adalah upaya yang dilakukan pemerintah untuk memperbaiki kondisi fisik pasar maupun tatakelolanya agar dapat menyesuaikan dengan perkembangan zaman. Revitalisasi pasar tradisional pada kenyataannya hanya sering merupakan upaya renovasi bangunan fisik pasar semata tanpa memikirkan perbaikan manajemen tata kelola.

Revitalisasi pasar tradisional berarti mensinergikan sumberdaya potensial yang dimiliki oleh pasar tradisional dengan mempertimbangkan seluruh aspek secara komprehensif, terintegrasi dan holistik sehingga mampu meningkatkan daya saing pasar tradisional dengan tetap mempertahankan kekhasan maupun keunggulan yang dimiliki pasar tradisional tersebut. Revitalisasi pasar tradisional dapat dilakukan dengan menata dan membenahi pasar tradisional, dimana kelemahankelemahan pada pasar tradisional yang menyebabkan penurunan daya saing pasar tradisional sendiri harus segera dibenahi. Tentunya, revitalisasi pasar tradisional membutuhkan kebijakan yang berpihak (affirmative action), baik pemerintah maupun seluruh stakeholder yang terkait.

\section{Manajemen Tata Kelola Pasar Tradisional}

Manajemen mengenai tata kelola pasar tradisional yang baik merupakan upaya untuk menjadikan pasar tradisional menjadi tempat yang nyaman untuk pedagang, parkir dan para kuli angkut erta juru bersih mencari pendapatan. Namun penelitian empiris yang dilakukan AC Nielson (2005) menunjukkan 3-5 tahun setelah renovasi dilakukan, kekumuhan terjadi berulang seperti sebelum renovasi. Bahkan terjadi pasar menjadi tidak seramai sebelum renovasi karena pelanggan merasa kesulitan menemukan pedagang langganannya yang losnya berubah atau tidak lagi berjualan. Selain itu tata kelola los (kebijakan lokasi) serta sewa los yang hanya bisa dibeli oleh pedagang yang mampu atau memiliki kedekatan dengan pengelola sehingga yang tidak mampu tersisih dan pindah di lokasi pasar yang sulit dijangkau konsumen pelanggannya ataupun karena sebab lain seperti zoning dengan pasar modern yang tidak diperhitungkan sehingga pelanggan lebih suka ke pasar modern.

Pengelola pasar tidak mampu menata keuangannya dengan baik sehingga laporan merugi dan tidak mampu membuat program program yang baik tentang tata kelola pasar sehingga gagal dalam membuat serta melaksanakan dan mengawasi standar operating prosedur tentang tata kelola pasar serta masalah premanisme dana parkir liar yang masih tetap ada. Pedagang yang ada tidak mampu merubah pola pikirnya dalam berdagang karena tidak ada upaya pendidikan tentang manajemen sehingga pelanggannya semakin sedikit dan lari ke pasar modern yang dikelola dengan baik. Dalam jangka panjang dikhawatirkan jumlah pedagang makin sedikit karena generasi muda tidak suka berdagang di pasar tradisional, lebih menyukai 
menjadi karyawan di pasar modern dan tidak menyukai berdagang ditempat yang tidak di-manage dengan baik karena penghasilannya tidak bisa diharapkan sebagai penopang hidup.

Berdasarkan kriteria dari Litbang Depdagri (1991). Manajemen tata kelola pasar dapat lihat efektifitasnya melalui :

a. Variabel Input : 1) Tingkat

Ketepatan Sasaran Program 2)

Sosialisasi Program 3) Tujuan

Program. Tingkat ketepatan sasaran program maksudnya adalah tepat atau tidaknya diberikannya program revitalisasi pasar tradisional oleh pemerintah daerah. Indikator ketepatan sasaran program dapat diukur dengan menghitung banyaknya responden atau pedagang yang merasa tepat atau tidaknya sasaran program revitalisasi

Sosialisasi program merupakan upaya-upaya yang dilakukan oleh pemerintah daerah untuk memberikan pemahaman dan pengertian kepada para pedagang sebagai calon penerima program revitalisasi pasar tradisional. Tujuan program adalah hasil yang diharapkan oleh pemerintah dari adanya pelaksanaan program revitalisasi. Indikator tujuan dari program ini dapat diukur dengan menghitung banyaknya jumlah responden yang mengetahui tujuan program revitalisasi

b. Variabel Proses: 1) Tingkat Kecepatan Respon Petugas 2) Tingkat Monitoring 3) Tingkat Evaluasi. ingkat kecepatan respon petugas maksudnya adalah kecepatan dalam daya tangkap petugas terhadap berbagai keluhan yang disampaikan pedagang pasar sebagai peserta program revitalisasi pasar tradisional.
Tingkat monitoring merupakan proses pengumpulan data, analisis data, dan informasi yang dilakukan oleh petugas dalam bentuk pemantauan langsung maupun tidak langsung yang sistematis serta berkelanjutan tentang program revitalisasi pasar agar dapat dilakukan tindakan koreksi guna penyempurnaan program. Indikator monitoring program dapat diukur dengan menghitung banyaknya jumlah responden yang mengetahui ada atau tidaknya kegiatan monitoring sebelum dan setelah program revitalisasi pasar. Tingkat evaluasi merupakan proses penilaian pencapaian tujuan dan pengungkapan masalah dalam pelaksanaan program revitalisasi pasar guna memberikan umpan balik dan peningkatan kualitas kinerja program. Indikator tingkat evaluasi diukur dengan cara menghitung banyaknya responden yang mengetahui ada atau tidaknya kegiatan evaluasi

c. Variabel Output yaitu ada perbedaan tingkat pendapatan pedagang sebelum dan sesudah proses revitalisasi pasar, Tingkat Pendapatan Pedagang maksudnya adalah peningkatan pendapatan yang diperoleh para pedagang Pasar

\section{METODOLOGI PENELITIAN}

Penelitian ini bertujuan untuk mengetahui dampak program revitalisasi pasar tradisional terhadap pendapatan pedagang serta mengetahui persepsi pedagang terhadap manajemen tata kelola pasar tradisional yang telah dilakukan berdasarkan input dan proses 
menggunakan menggunakan kriteria efektivitas Litbang Depdagri (1991).

\section{Populasi dan Teknik Pengambilan Sampel}

Populasi penelitian ini adalah pedagang di pasar tradisional di Pasar Tumenggungan di lantai 1 dan di emperan kios di lantai 1, sedangkan sampel penelitian adalah 100 responden. Teknik pengambilan sampel menggunakan non-probability sampling dengan sampling sistematis, yaitu memilih sampel dari suatu urutan daftar menurut urutan tertentu, misal tiap individu urutan no 17 ke-n $(10,15,20$ dst). Frankel dan Wallen (1993:92) menyarankan besar sampel minimum untuk penelitian deskriptif sebanyak 100 sampel.

\section{Analisis Data}

Sebelumnya akan dilakukan 3 tahap pengujian terhadap data yang telah dikumpulkan melalui analisis instrumen yaitu uji validitas, uji reliabilitas dan uji normalitas. Uji validitas ditentukan oleh nilai signifikasi. Menurut Sudarmanto (2005), validitas dapat dilakukan dengan mengkorelasi antara skor item instrumen dengan skor total seluruh pertanyaan.

\section{Hipotesis Statistik}

H0: Tidak terdapat perbedaan antara pendapatan sebelum dan sesudah dilaksanakan program revitalisasi pasar tradisional di pasar Tumenggungan

H1: terdapat perbedaan antara pendapatan sebelum dan sesudah dilaksanakan program revitalisasi pasar tradisional di pasar Tumenggungan

\section{HASIL DAN PEMBAHASAN}

\section{ANALISIS DESKRIPTIF}

Sebagian besar responden berjenis kelamin perempuan yaitu sebanyak $76 \%$. persen, sedangkan sisanya adalah laki-laki. Ini menunjukkan bahwa peran perempuan mendominasi dalam mencari pendapatan bagi keluarga pada responden penelitian ini

Sebagian besar responden merupakan tenaga kerja produktif, dengan range usia antara 26 hingga 56 tahun. Mayoritas responden masuk dalam kelompok usia kurang dari 25 tahun sebesar $8 \%$, responden yang termasuk dalam usia $26-35 \%$ sebanyak $25 \%$ persen dan yang berusia $36-45$ tahun sebanyak $22 \%$, antara sedangkan sisanya berusia lebih dari 46 tahun sebanyak $45 \%$. Ini juga menunjukkan berkarir di pasar tradisional di kebumen masih disukai oleh kalangan muda

Tingkat pendidikan responden bervariasi mulai dari SD hingga perguruan tinggi. Mayoritas responden yaitu sebesar 44\% merupakan lulusan SLTP. Sebayak $31 \%$ berasal dari lulusan SD, $24 \%$ lulusan SLTA dan hanya $1 \%$ lulusan perguruan tinggi. Ini menunjukkan para pedagang yang berjualan di Pasar Tumenggungan memang berpendidikan dasar, sedangkan lulusan pendidikan tinggi tidak menunjukkan minat untuk berjualan di pasar tradisional. Fenomena ini didukung oleh tabel 5 yang menunjukkan bahwa para pedagang adalah para pemain lama, sedangkan orang-orang baru hanya $14 \%$ (yang menekuni usaha 1-5 tahun setelah revitalisasi pasar).

Dari lamanya masa berusaha, tabel 5 menunjukkan bahwa $52 \%$ pedagang telah menekuni usaha berdagangnya di pasar Tumenggungan lebih dari 5 tahun, $34 \%$ responden telah menekuni usaha 3-5 tahun, $12 \%$ responden telah menekui usaha ini selama $1-3$ tahun dan hanya $2 \%$ dari jumlah responden yang baru menekuni 
usaha setahun sebelum revitalisasi

pasar Tumenggungan. Ini menunjukkan sebagian besar para pedagang adalah para pemain lama yang memiliki pelanggan masingmasing sehingga memahami akan adanya program revitalisasi pasar tradisional.

Sebaran pedagang yang menempati lantai II adalah $49 \%$ dan $51 \%$ ada di lantai I. Sehingga dapat menggambarkan keseluruhan persepsi pelanggan.

ANALISIS PERSEPSI DAMPAK PROGRAM REVITALISASI PASAR MENURUT PEDAGANG

Dampak program revitalisasi pasar Tumengungan dapat dilihat dari input, proses dan output dengan indikator-indikator sebagai berikut:

\section{Input}

Analisis input program revitalisasi pasar meliputi:

a. Persepsi pedagang akan perlunya program revitalisasi dilaksanakan

Sebagian besar $(91 \%)$ responden sepakat bahwa pasar Tumenggungan memang sudah perlu dilakukan program revitalisasi pasar.

b. Adanya sosialisasi program revitalisasi pasar kepada pedagang

$81 \%$ responden setuju telah diadakannya program sosialisasi dan $23 \%$ sangat setuju telah diadakannya sosialisasi program revitalisasi pasar tradisional oleh pedagang.

c. Persepsi mengetahui pedagang tujuan diadakannya program
Sebanyak $77 \quad \%$ responden dagang yang mengetahui tujuan dilaksanakannya revitalisasi

\section{Proses}

Efektifitas program revitalisasi pasar tradisional dari proses pada pasar Tumenggungan dapat diketahui dari indikator-indikator sebagai berikut:

a. Kebersihan pasar dievaluasi secara berkala Berdasarkan hasil perhitungan kuesioner maka persepsi pedagang mengenai dievaluasinya kebersihan pasar adalah setuju akan dievaluasinya kebersihan pasar adalah $89 \%$

b. Kebersihan fasilitas umum (toilet, mushola) dievaluasi secara berkala

Ini menunjukkan bahwa sebagian besar responden setuju kebersihan fasilitas dievaluasi secara berkala setelah program revitalisasi (90\%)

c. Respon terhadap keluhan ditangani dengan cepat

Sebanyak $65 \%$ responden bahwa respon petugas dalam menangani masalah adalah cepat (responsif)

Hasil wawancara menunjukkan masih ada keluhan tentang respon petugas yaitu ketika menarik retribusi sangat responsif, namun untuk keluhan kecepatan responnya lebih lambat. 
d. Koordinasi petugas terlihat bagus dalam menangani masalah

Persepsi pedagang mengenai koordinasi petugas dalam menangani masalah 69 $\%$ setuju telah adanya koordinasi petugas dalam menangani masalah.

e. Terdapat monitoring program secara berkala

Persepsi pedagang terhadap monitoring program-program revitalisasi secara berkala yang dilakukan pemerintah dalam hal ini pelaksananya adalah Dinas Perindustran Perdagangan dan Pasar. 77 $\%$ setuju telah dilakukan monitoring program secara berkala.

f. Petugas melakukan evaluasi rutin

Dapat disimpulkan bahwa dilihat dari keseluruhan proses, para pedagang menyatakan bahwa proses berjalan dengan baik ditandai oleh baiknya Kebersihan pasar, Kebersihan fasilitas umum, Respon terhadap keluhan ditangani dengan cepat, Koordinasi petugas terlihat bagus dalam menangani masalah, Terdapat monitoring, petugas melakukan evaluasi akan adanya kerusakan dan hal-hal yang berkenaan dengan kebersihan fasilitas

Namun perlu dicatat bahwa dalam wawancara banyak pedagang yang mengeluhkan petugas hanya sigap saat menarik retribusi dan pelatihan tentang pembukuan perlu dilakukan dan fasilitas tangga menuju lantai II masih sedikit

\section{Output}

$\begin{array}{ll}\text { Output } & \text { program } \\ \text { revitalisasi pasar modern }\end{array}$ adalah kenaikan pendapatan pedagang

Pendapatan pedagang adalah pendapatan per hari yang diterima oleh pedagang di Pasar Tumenggungan, baik sebelum maupun sesudah dilakukan program revitalisasi pasar oleh pemerintah Kabupaten Kebumen. Dalam analisis, pendapatan pedagang terdapat empat kelompok pedagang., yaitu 1 . Menyatakan sangat tidak setuju setelah revitalisasi pasar pendapatan meningkat 2 . Menyatakan tidak setuju setelah revitalisasi pasar pendapatan meningkat 3 . Menyatakan setuju setelah revitalisasi pasar pendapatan menimgkat 4. Menyatakan sangat setuju setelah revitalisasi pasar pendapatan meningkat berdasarkan empat kategori tersebut maka tabel dibawah ini menunjukkan:

Berdasarkan tabel diatas terlihat bahwa $29 \%$ pedagang menyatakan ketidak setujuannya setelah revitalisasi pasar , pendapatan mereka meningkat. Ini artinya mereka mengalami penurunan pendapatan setelah program revitalisasi pasar dilaksanakan. Sedangkan $71 \%$ menyatakan setuju dan sangat setuju bahwa setelah program revitalisasi pasar pendapatan mereka meningkat

Sebanyak 29\% persen responden mengakui mengalami penurunan pendapatan sesudah diadakan program pembenahan pasar. Penurunan pendapatan ini 
terjadi lebih banyak pada pedagang pakaian, sepatu/sandal yang lokasinya berada di lantai II.

Program revitalisasi pasar yang dilakukan oleh pemerintah Kabupaten Kebumen yaitu dengan pembenahan dan penataan pasar di Pasar Tumenggungan menyebabkan perubahan pada tempat maupun posisi pedagang los. Beberapa pedagang yang tingkat pendapatannya menurun setelah diadakannya pembenahan pasar mengakui penurunan tingkat pendapatan disebabkan oleh perubahan posisi berjualan.

Sebelumnya, beberapa pedagang diuntungkan oleh posisi berdagang yang lebih berada di depan dibandingkan pedagang lainnya yang sejenis. Posisi ini dianggap strategis karena lebih mudah dijangkau oleh pembeli. Setelah program revitalisasi, los-los untuk jenis dagangan yang sama diatur berderet. Ini menyebabkan pembeli dengan mudah berpindah dari satu pedagang ke pedagang lainnya apabila tidak menemukan barang yang diinginkan atau pun apabila tidak ada kesepakatan harga dengan salah satu pedagang. Hal ini menyebabkan persaingan antara pedagang semakin ketat.

Keberadaan pasar pagi di sebelah timur pasar mulai jam 5.00 pagi sampai jam 8.00 pagi dikeluhkan pedagang yang berjualan di siang hari. Ini menyebabkan pendapatan berkurang karena pelanggan berbelanja di pasar pagi.

\section{Uji beda pendapatan sebelum dan sesudah revitalisasi}

Untuk menguji kuesioner dilakukan pengujian validitas dengan menggunakan teknik korelasi product moment, diperoleh nilai koefisien korelasi untuk pendapatan sebelum revitalisasi sebesar 0,980 dan untuk pendapatan sesudah revitalisasi sebesar 0,987 , yang menunjukkan bahwa indikator pertanyaan adalah valid. Pengujian reliabilitas yang dilakukan dengan menggunakan koefisien Alpha Cronbach, diperoleh nilai sebesar 0,955 yang menunjukkan variabel adalah reliabel. Uji normalitas dengan menggunakan metode one-sample KolmogorovSmirnov menunjukkan data tidak berdistribusi normal, sehingga syarat pengolahan data dengan metode parametrik tidak terpenuhi. ebelum dan sesudah program revitalisasi pasar digunakan uji beda dengan metode nonparametrik yaitu metode Wilcoxon.

Tabel 18 Uji Validitas

\begin{tabular}{|l|l|l|}
\hline & R hitung & Kesimpulan \\
\hline Sebelum program revitalisasi & 0,980 & valid \\
\hline Sesudah program revitalisasi & 0,987 & Valid \\
\hline
\end{tabular}

Sumber: data primer diolah 2016 
Tabel 19 Uji reliabilitas

\begin{tabular}{|l|l|l|}
\hline & $\begin{array}{l}\text { Alpha } \\
\text { Cronbach }\end{array}$ & Kesimpulan \\
\hline Alpha Cronbach & 0,955 & Relialibel \\
\hline
\end{tabular}

Sumber: data primer diolah 2016

Tabel 18 Hasil Uji Beda Wilcoxon

Test Statistics $^{\mathrm{a}}$

\begin{tabular}{|l|r|}
\hline & \multicolumn{1}{|c|}{$\begin{array}{c}\text { Pendapatan setelah } \\
\text { revitalisasi - pendapatan } \\
\text { sebelm revitalisasi }\end{array}$} \\
\hline $\begin{array}{l}Z \\
\begin{array}{l}\text { Asymp. Sig. (2- } \\
\text { tailed) }\end{array}\end{array}$ & $-3,302^{\mathrm{b}}$ \\
\hline
\end{tabular}

a. Wilcoxon Signed Ranks Test

b. Based on negative ranks.

Sumber: Data primer , 2016

Berdasarkan hasil pengolahan dengan metode Wilcoxon, diperoleh nilai $\mathrm{z}$ hitung sebesar -3,02 dan Asymp. Sig. (2-tailed) adalah 0,01. Nilai probabilitas signifikansi ini lebih rendah dari $\alpha=0,05$. Ini berarti H0 ditolak, sehingga dapat disimpulkan pendapatan pedagang di pasar Tumenggungan sebelum dan sesudah program revitalisasi berbeda secara signifikan. Uji beda pada penelitian ini dilakukan untuk membuktikan hipotesa atau dugaan awal penelitian yaitu H0 yang menyatakan bahwa tidak ada perbedaan pendapatan pedagang pasar tumengungan sebelum dan sesudah revitalisasi pasar, dan $\mathrm{Ha}$ yang menyatakan bahwa terdapat perbedaan pendapatan pedagang pasar tumenggungan sebelum dan sesudah dilakukan revitalisasi.
IV. Kekurangan dari Program Revitalisasi dan Saran Responden

Kekurangan-kekurangan program revitalisasi yang kemudian muncul terungkap dalam pernyataan terbuka dalam kuesioner yang dapat dirangkum sebagai berikut

1. Parkir panas

Pedagang merasakan bahwa area parkir yang ada panas karena tidak beratap.

2. Kekurangan parkiran

Lahan parkir dirasakan kurang luas.

3. Jalur evakuasi belum ada Belum dilengkapinya jalur evakuasi, sehingga jika terjadi bencana pengunjung dan pedagang pasar terancam jiwanya.

4. Kurang memperhatikan masalah sepele

Pengelola pasar kurang memperhatikan masalahmasalah sepele yang terjadi. Padahal masalah sepele yang 
terjadi memiliki potensi untuk menjadi besar.

5. Tidak teratur

Penataan kios terlihat lebih semrawut, sehingga kurang sedap dipandang mata.

6. Lantai licin jika hujan Lantai pasar licin jika terjadi hujan, sehingga pengunjung dan pedagang pasar rawan terpeleset di dalam pasar.

7. Kurangnya perawatan terhadap fasilitas

Fasilitas yang dimiliki oleh pasar tumenggungan kurang dirawat sehingga lebih cepat rusak.

8. Petugas hanya aktif menarik retribusi

Petugas yang ada hanya aktif menarik retribusi tapi kurang aktif dalam kegiatan yang lain.

9. Tertibkan pedagang di pinggir jalan

Banyak terdapat pedagang yang berjualan di luar area pasar tumenggungan. Hal ini menyebabkan pembeli tidak mau masuk ke dalam pasar sehingga merugikan pedagang yang berjualan di dalam pasar.

10. Kios/lapak berjualan menjadi sempit

Kios atau lapak yang tersedia saat ini lebih sempit jika dibandingkan dengan saat belum dilakukan revitalisasi.

11. Sampah kurang terurus Tempat sampah yang terbatas jumlahnya merupakan faktor yang menjadikan sampah pasar teronggok di beberapa lokasi menimbulkan aroma dan pemandangan yang kurang baik

12. Pembeli di lantai II berkurang
Hal ini paling dikeluhkan oleh semua penghuni lantai II, bahwa pengunjung menjadi berkurang. Apalagi eskalator menuju lantai II tidak difungsikan setelah adanya kecelakaan dan kurangnya tangga menuju ke lantai II, panas karena sirkulasi udara buruk, sempitnya antar kios ditengarai menjadi penyebab turunnya pelanggan

13. Banyak yang berjualan di pinggir jalan, sehingga pembeli tidak masuk pasar dikeluhkan pedagang yang menyewa kios di dalam pasar.

14. Kaca eskalator kotor karena jarang dibersihkan

15. Kurang ventilasi sehingga panas menyengat saat cuaca panas

16. Gang sempit terutama dilantai II

17. Pembeli sedikit sampai tidak mampu bayar abondemen. Ini dikeluhkan pedagang sepatu, tas dan sandal di lantai II

18. Respon lambat dari beberapa petugas, hanya sigap saat menarik rertribusi

19. Sewa kios relatif mahal

20. Petugas tidak sigap menghadapi masalah

Saran-saran dari pedagang terhadap program revitalisasi pasar tradisional antara lain:

1. Dibuatkan jalur evakuasi

2. Penambahan filter

3. Fasilitas lebih dilengkapi

4. Diadakan pelatihan agar siap menghadapi MEA

5. Awasi tengkulak cabe

6. Kebersihan ditingkatkan

7. Eskalator agar dihidupkan 
8. Pintu masuk tengah sebelah selatan jangan dipenuhi pedagang mengganggu pengunjung lewat

9. Gerbang dibuka semua

10. Pedagang yang berjalan di depan pintu pasar agar masuk saja sehingga pelanggan masuk pasar

11. Diperlukan ketegasan petugas, peraturan yang berlaku tetap diberlakukan

\section{SIMPULAN DAN SARAN}

Berdasarkan hail penelitian yang dilakukan dengan metode peyebaran kuesioner, wawancara dengan petugas dan daftar pustaka maka kesimpulan yang dapat diambil adalah:

1. Pada awalnya Pasar Tumenggungan hanyalah sebuah pasar Desa yang dimiliki oleh Desa Kebumen. Pasar Tumenggungan merupakan penggabungan antara dua pasar di Kota Kebumen, yaitu antara pasar Sungai Luk Ulo dengan Pasar Desa Kebumen. Menurut Jumali (2011), Pasar Tumenggungan diperkirakan dibangun pada tahun 1670-an.

2. Pada tahun 2013 Pemerintah Kabupaten Kebumen melakukan revitalisasi pasar tersebut. Hal ini dilakukan Pemerintah Kabupaten Kebumen sebagai upaya beradaptasi dengan munculnya pasar-pasar modern yang lebih bersih dan nyaman. Sebelum di revitalisasi kondisi fisik bangunan sudah tua, penataan pedagang masih semerawut, jika hujan becek, banyaknya parkir liar. Tujuan lain dari revitalisasi pasar Tumenggungan adalah untuk lebih menarik pembeli berbelanja di pasar tradisional sehingga terjadi peningkatan transaksi jual beli, secara otomatis pendapatan pedagang mengalami peningkatan

3. Sebelum direvitalisasi pasar Tumenggungan hanya mampu menampung 3.000 pedagang, tetapi setelah direvitalisasi mampu menampung sebanyak 3.123 pedagang.

4. Berdasarkan hasil kuesioner persepsi pedagang terhadap program revitalisasi maka disimpulkan pedagang menyatakan setuju perlu adanya program revitalisasi pasar, mereka mengetahui tujuan program ini karena adanya sosialisasi yang cukup akan revitalisasi fisik serta imbas positif lainnya

5. Berdasarkan hasil kuesioner persepsi pedagang tentang proses yang berlangsung setelah program revitalisasi pasar adalah para pedagang menyatakan bahwa proses berjalan dengan baik ditandai oleh baiknya Kebersihan pasar, Kebersihan fasilitas umum, Respon terhadap keluhan ditangani dengan cepat, Koordinasi petugas terlihat bagus dalam menangani masalah, Terdapat monitoring, petugas melakukan evaluasi akan adanya kerusakan dan hal-hal yang berkenaan dengan kebersihan fasilitas

6. Berdasarkan hasil kuesioner persepsi pedagang sebanyak 71 $\%$ menaakan setelah adanaya progam revitalisasi pasar Tumenggungan pendapatan mereka meningkat sedangkan 29 $\%$ menyatakan menurun. Hasil penelusuran kuesioner, penurunan pendapatan dirasakan pedagang di lantai II. 
Hasil uji statistik dengan menggunakn uji wilcoxon menyataakan bahwa terdapat perbedaan pendapatan sebelum dan sesudah revitalisasi. Nilai signifikansi yang diperoleh adalah sebesar 0,001 yang $\mathrm{H} 0$ pada penelitian ini ditolak dan $\mathrm{Ha}$ diterima, artinya terdapat perbedaan pendapatan pedagang pasar Tumenggungan sebelum dan sesudah dilakukan revitalisasi pasar.

\section{Kelemahan penelitian}

Penelitian ini dilakukan pada tahun ketiga program revitalisasi pasar sehingga pada pertanyaan-pertanyaan untuk input dan proses tidak ditanyakan persepsi pedagang sebelum program revitalisasi. Sebaiknya penelitian ini dilakukan setahun setelah revitalisasi pasar dan dilakukan kajian ulang sehingga dampak progam bisa dievaluasi. Kurang menyeluruhnya kajian dampak revitalisasi dengan adanya kenaikan pertumbuhan pasar modern tidak dikaji dalam penelitian ini, sehingga tidak terdeteksi hal-hal apa saja yang mempengaruhi adanya penurunan pendapatan pada pedagang pasar Tumenggungan.

\section{Saran}

Upaya revitalisasi pasar tradisional sebaiknya tidak hanya terhenti pada pembenahan lingkungan fisik pasar saja, melainkan harus dilanjutkan dengan berbagai upaya untuk memperbaiki segala aspek mulai dari jaringan suplai barang dagangan, akses permodalan, manajemen, penataan dan pengelolaan parkir, hingga pelatihan manajemen serta ilmu berdagang. Berdasarkan wawancara memang masih belum ada progrgam pelatihan dari Dinas Pasar. Pedagang sebenarnya membentuk paguyuban namun keberadaannya juga belum mampu menghasilkan perbaikan secara komunitas.

Agar pengelola pasar bisa memberkan fasilitas infrastrukturnya dan menata lay out pasar terutama untuk barang slow moving ditemapatkan diarea yang mudah terlihat konsumen dan dilalui konsumen. Prinsip ini meniru pengelolaan ritel modern.

Pengelolaan pasar tradisional tidak hanya menjadi tugas pemerintah daerah, tetapi juga masyarakat, pengelola pasar, dan para pedagang pasar tradisional itu sendiri. Hal ini untuk menciptakan rasa kepemilikan yang tinggi sehingga kondisi pasar tradisional yang sudah baik dapat bertahan dan berkelanjutan. Kemitraan juga dipentingkan untuk bersama-sama meningkatkan citra pasar tradisional yang, bersih, indah, aman dan nyaman untuk berusaha, berbelanja maupun berinteraksi. Zoning pasar tradisional dan ritel modern memang sudah sepantasnya ada legalitas formalnya. Jarak antar pasar modern dan tradisional yang terlalu dekat akan merugikan pasar tradisional pada masyarakat modern yang gemar berbelanja sebagai hedonisme. 


\section{DAFTAR PUSTAKA}

Dessler, Gary. 2007. Manajemen Personalia, Edisi Ketiga, Jakarta: Erlangga

Gibson, J.L. Ivancevich dan JH. Donnely, (1985), Organisasi dan Manajemen: Perilaku, Struktur, Proses. Editor: Agus Dharma. Jakrta: Erlangga.

Handoko, $\mathrm{T}$ Hani. 2004.Manajemen Personalia dan Sumberdaya Manusia. Yogyakarta: BPFE

Hasibuan, Malayu S. P. 2008. Manajemen Sumber Daya Manusia.Jakarta: PT. Bumi Aksara

Luthans, Fred. 2006. Perilaku Organisasi, Alih Bahasa V.A Yuwono. Yogyakarta : Adhityo

Malayu Hasibuan. 2002. Manajemen Sumberdaya Manusia, Jakarta: PT. Bumi Aksara

Mathis Robert L dan Jackson John H. 2002. Human Resoursce Management, Alih Bahasa. Jakarta : Salemba Empat.

Munandar, ashar sunyoto. 2010. Psikologi Industri dan Organisasi. Jakarta: Universitas Indonesia

Nitisemito, Alex.S. 2001. Manejemen Personalia Manajemen Sumber Daya Manusia. Edisi keempat. Jakarta: Ghalia Indonesia.

Robbins, Stephen P.2001. Perilaku Organisasi, Edisi kedelapan, PT.Prenhalindo, Jakarta

Robbins, Stephen P. dan Timothy A. Judge. 2008. Perilaku Organisasi Edisi ke-12, Jakarta: Salemba Empat.

Simamora, Henry.2004.Mnanajemen Sumberdaya Manusia. Yogyakarta SIE YKPN

Steers, R.M (1985), Efektifitas Organisasi. Erlangga, Jakarta.

Wijono, sutarto. 2010. Psikologi industri dan Organisasi. Jakarta: Kencana Prenada media group 